\title{
SEMINOMA ANAPLASTIK DENGAN YOLK SAC TUMOR TESTIS (MIXED GERM CELL TUMOR TESTIS)
}

\author{
Lily L. Loho
}

\author{
Laboratorium Patologi Anatomi Fakultas Kedokteran Universitas Sam Ratulangi Manado \\ Email: lily_loho@yahoo.com
}

\begin{abstract}
Testicular cancer is relatively rare, accounting for less than $1 \%$ of malignant tumors affecting men. More than $90 \%$ of these tumors are of germ cell origin and most of them are found in young men between the ages of 15-34 years. Germ cell tumors are divided into seminoma and nonseminoma tumors. The seminoma makes up 30-40\% of all testicular tumors. An anaplastic seminoma is a classic type of seminoma that has three or more mitosis under the high power microscopic field, combined with other morphologic criteria such as nuclear hyperchromasia, greater nucleolar sizes, pleomorphism, and an amount of necrosis. We reported a case of a 38-year-old male that was clinically diagnosed with a left testicular tumor and with an elevated alpha fetoprotein (AFP) and $\beta$ human chorionic gonadotropin ( $\beta$ HCG) serum. The histopathological diagnosis was an anaplastic seminoma with a yolk sac tumor (YCT), i.e. a mixed germ cell tumor.
\end{abstract}

Keywords: seminoma, testicular tumor, yolk sac tumor.

\begin{abstract}
Abstrak: Kanker testis relatif jarang, <1\% dari semua kanker ganas pada laki-laki. Lebih dari 90 persen jenis tumor ini berasal dari sel germinal dan umumnya menyerang laki-laki muda berusia 15-34 tahun. Tumor sel germinal dibagi atas dua jenis: seminoma dan non seminoma. Jenis seminoma terdapat pada 30-40\% dari seluruh tumor testis. Seminoma anaplastik adalah seminoma dengan ciri klasik mikroskopik berupa adanya tiga atau lebih sel-sel mitosis per lapangan pandang besar, disertai terdapatnya kriteria morfologik lain seperti inti sel hiperkromatik, anak inti berukuran besar, pleomorfik, dan terdapatnya sejumlah nekrosis. Kami melaporkan kasus seorang laki-laki berusia 38 tahun dengan diagnosis klinis tumor testis kiri disertai peningkatan kadar alfa feto protein (AFP) dan $\beta$ human chorionic gonadotropin ( $\beta$ HCG) serum. Diagnosis histopatologik ialah seminoma anaplastik dengan tumor yolk sac (YCT), yaitu tumor sel germinal campuran.
\end{abstract}

Kata kunci: seminoma, tumor testis, tumor yolk sac.

Keganasan testis relatif jarang ditemukan, $<1 \%$ dari semua tumor ganas pada lakilaki. Umumnya tumor testis (>90\%) berasal dari sel germinal dan ditemukan pada usia 15-45 tahun. ${ }^{1,2}$ Puncak kedua keganasan testis terjadi pada usia 80-90 tahun dan kebanyakan merupakan tumor metastasis. Germ cell tumor dibagi atas seminoma dan non-seminoma. Seminoma mencakup 30-40\% dari semua tumor testis. ${ }^{3}$ Pada tahun 2001 sekitar 12.500 kasus baru germ cell tumor didiagnosis di
Amerika Serikat. Insidens bervariasi menurut area geografi, insidens tertinggi sekitar 9 per 100.000 populasi laki-laki di Denmark dan Swis. ${ }^{1}$ Di Amerika Serikat insidens tumor ini sekitar 5,4 per 100.000 laki-laki dengan variasi rasial pada kulit putih empat kali lebih banyak dari pada Afro-Amerika. ${ }^{1,4,5}$ Penyebab terjadinya peningkatan insiden tumor ini di seluruh dunia tidak jelas. ${ }^{6,7} \mathrm{Di}$ berbagai negara di Eropa insidens meningkat sekitar 2-5\% per tahun sedangkan di Amerika Serikat insi- 
dens meningkat 52\% dari pertengahan tahun 1970 sampai pertengahan tahun $1980 .^{8}$

Lebih dari separuh tumor ini terdiri lebih dari satu jenis tumor (mixed germ cell tumor). ${ }^{6,7}$ Berdasarkan hal ini pengambilan sampel jaringan harus dilakukan dengan cermat untuk mendapatkan hasil diagnosis yang tepat. Selain itu, korelasinya dengan penanda tumor serum human chorionic gonadotropin (HCG) dan alpha feto protein (AFP) perlu dipertimbangkan. ${ }^{9}$ Beberapa faktor yang berhubungan dengan germ cell tumor ialah: cryptorchidism, predisposisi familiar, germ cell tumor pada testis kontralateral, gonadal dysgenesis, androgen insensitivity syndrome, dan infertilitas. ${ }^{1,10}$

\section{LAPORAN KASUS}

Seorang laki-laki berusia 38 tahun dengan diagnosis klinis tumor testis sinistra. Hasil pemeriksan darah untuk $\beta$ HCG 1,026 mIU/ml dan AFP 1.069 ng/ml. Pada pasien dilakukan operasi pengangkatan tumor testis.

Gambaran makroskopik jaringan tumor berukuran $8 \times 4 \times 6 \mathrm{~cm}$, konsistensi kenyal, dan tidak berkapsul. Pada potongan tampak jaringan putih padat disertai sedikit foki perdarahan (Gambar 1). Gambaran mikroskopik menunjukkan sel-sel tumor yang tersebar difus dan banyak sekat jaringan ikat padat dengan infiltrasi limfosit (Gambar 2). Sel tumor pleomorfik, inti besar di tengah dengan nukelolus jelas, sitoplasma agak jernih, dan batas sel jelas. Terdapat sel-sel bermitosis (Gambar 3), jaringan nekrosis yang cukup luas serta tersebar beberapa sel Datia (Gambar 4). Gambaran histopatologik ini sesuai dengan seminoma anaplastik. Oleh karena kadar AFP tinggi, maka dilakukan pemeriksaan jaringan pada bagian tumor lainnya dan didapatkan proliferasi sel-sel yang relatif sedikit sitoplasma, globul hialin pada beberapa sel (Gambar 5), serta pembentukan mikrokistik dan makrokistik. Diagnosis yang ditegakkan ialah seminoma anaplastik dengan yolk sac tumor (YST, Gambar 6), jadi merupakan suatu mixed germ cell tumor.

\section{BAHASAN}

Germ cell tumor yang terdiri lebih dari satu komponen disebut mixed germ cell tumor (MGCR) dan merupakan tumor testis germ cell kedua terbanyak, \pm 40-50\% dari semua tumor primer germ cell.

Kombinasi dari tiap komponen germ cell dapat ditemukan, tetapi yang tersering ialah kombinasi karsinoma embrional dan teratoma (26\%); karsinoma embrional dan seminoma (16\%); serta karsinoma embrional, YST, dan seminoma (10\%). Pada masa prepubertas jarang ditemukan MGCT. ${ }^{1,5,11}$ Setelah pubertas, YST hampir selalu merupakan salah satu komponen pada sekitar 44\% kasus MGCT dewasa.,12 Pembesaran testis tanpa nyeri yang disertai peningkatan AFP serum dan $\beta H C G$, umumnya menggambarkan suatu MGCT. ${ }^{10}$ Peningkatan AFP serum meningkat pada 95-100\% pasien dengan komponen YST pada tumor. ${ }^{1}$ Umumnya YST ditemukan sebagai fokus kecil, dan biasanya ditutupi oleh komponen lain. MGCT dengan komponen seminoma ditemukan pada usia yang lebih lanjut dari pada MGCT tanpa komponen seminoma. Secara histologik pada MGCT ditemukan 59\% dengan seminoma, $41 \%$ dengan YST, dan 47\% dengan karsinoma embrional dan teratoma. ${ }^{9}$ Hal tersebut sesuai dengan kasus ini dimana sebagian besar tumor berupa komponen seminoma dan hanya sebagian kecil YST. Stamatiou et $\mathrm{al}^{13}$ melaporkan kasus MGCT pada seorang laki-laki Kaukasia berusia 32 tahun dengan seminoma dan komponen teratoma imatur dari rabdomiosarkoma, yang meninggal akibat metastasis paru dua bulan setelah pemberian terapi. Seminoma dapat dilihat sebagai bagian dari MGCT tetapi pada beberapa kasus seminoma tampak terpisah. ${ }^{13}$ Pada dewasa komponen YST ditemukan sampai $45 \%$ dari non seminomatous germ cell tumor (NSGCT). ${ }^{14}$

Seminoma dengan jumlah mitosis $>3$ per lapang pandang besar disebut seminoma anaplastik. ${ }^{1,7}$ Penamaan yang lebih sesuai ialah seminoma dengan derajat mitosis tinggi, karena derajat anaplasia 


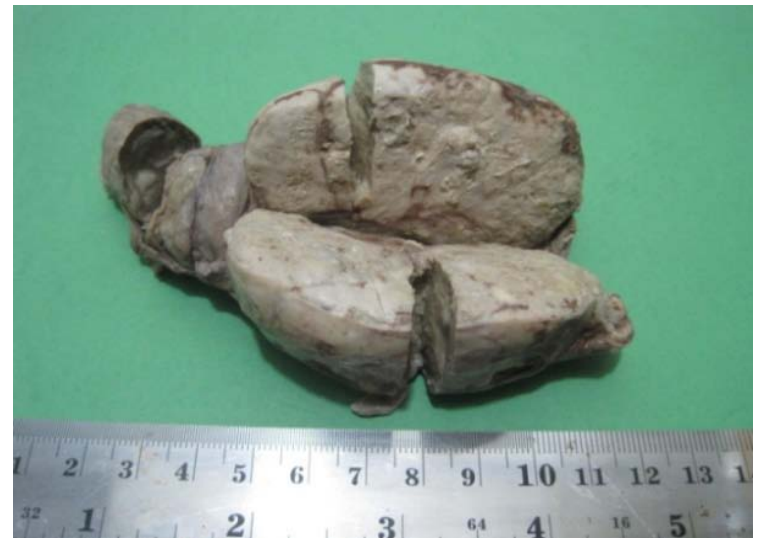

Gambar 1. Tumor berwarna putih dengan konsistensi kenyal.

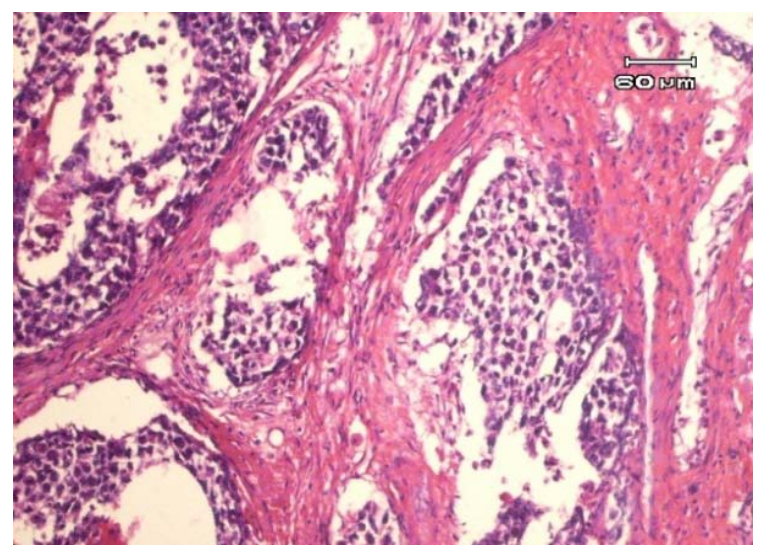

Gambar 2. Sel-sel tumor tersebar difus dan tampak banyak sekat jaringan ikat.

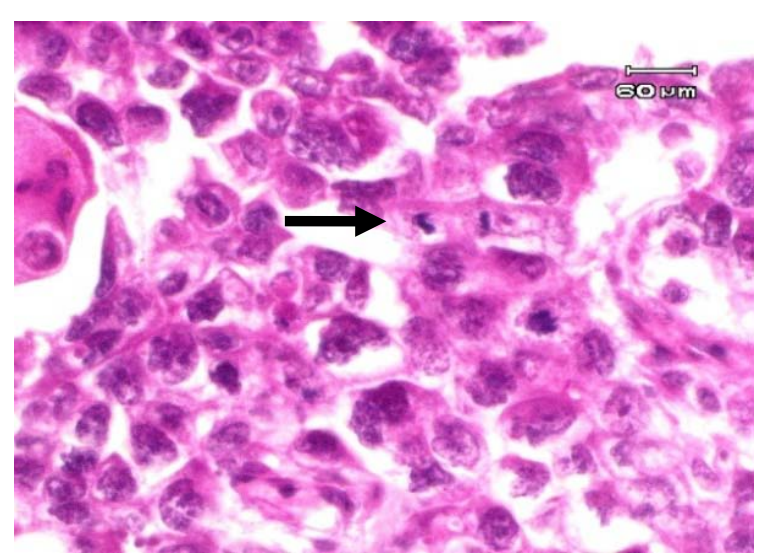

Gambar 3. Sel-sel pleomorfik dan sel-sel yang bermitosis.

tidak lebih tinggi dari seminoma klasik. Aktivitas proliferasi tinggi dilihat dari jumlah mitosis atau deteksi positif sel tumor dengan penanda proliferasi (ki67). ${ }^{15}$ Peneliti lain mengombinasikan derajat

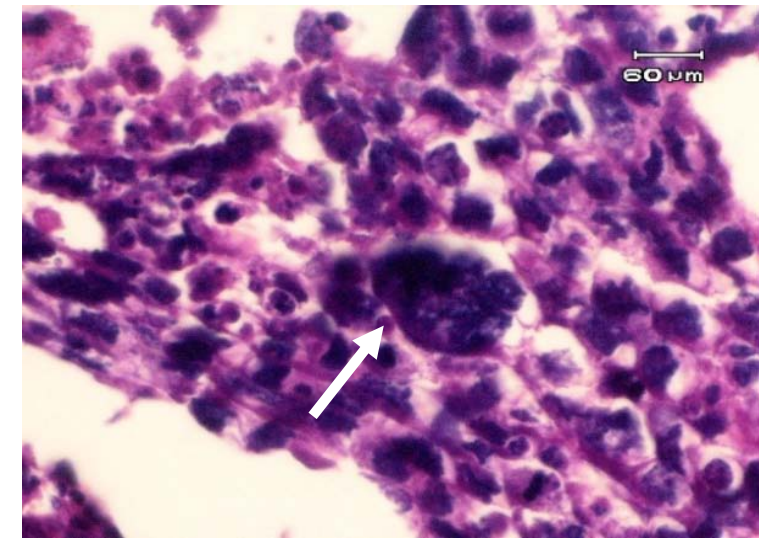

Gambar 4. Sel datia (anak panah).

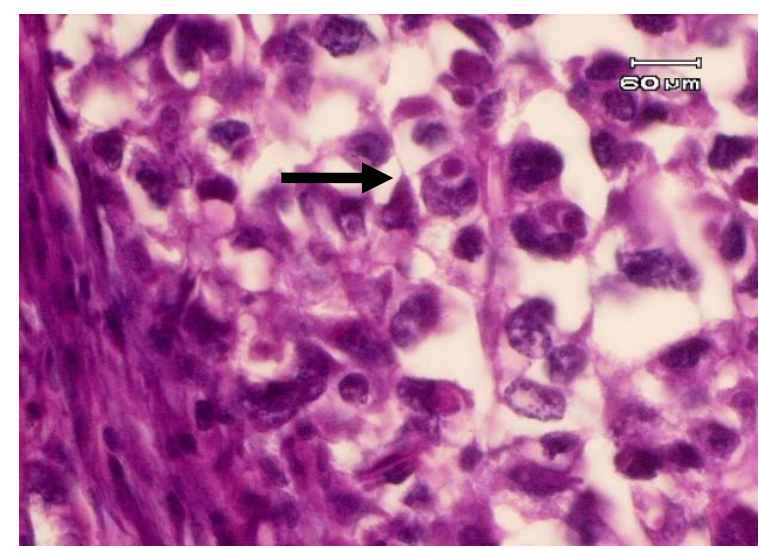

Gambar 5. Globul hialin intraseluler (anak panah).

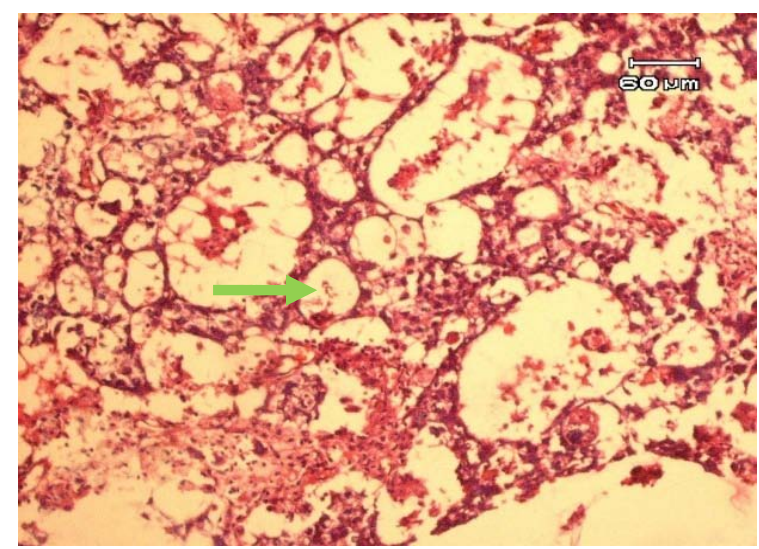

Gambar 6. Komponen yolk sac tumor.

mitosis dengan kriteria morfologik seperti inti hiperkromatik, ukuran nukleolus besar, sel-sel pleomorfik, dan jumlah nekrosis pada seminoma anaplastik. ${ }^{7}$ Pada kasus ini sebagian besar tumor berupa seminoma 
anaplastik dengan bagian nekrosis cukup banyak.

Dari sejumlah besar penanda serum yang telah diteliti, hanya $\beta$ HCG, AFP, dan laktase dehidrogenase (LDH) yang mempunyai nilai diagnostik dan prognostik independen untuk keganasan testis., ${ }^{2,6}$

Pada kultur sel tumor, $\beta$ HCG merangsang pertumbuhan sel melalui pencegahan terjadinya apoptosis. Seminoma dapat memroduksi $\beta \mathrm{HCG}^{8}$ dimana kadarnya dalam serum meningkat ringan pada $7-25 \%$ kasus, $^{14}$ terlebih lagi pada pasien dengan metastasis. ${ }^{1}$ Sel-sel sinsitiotrofoblas ditemukan hingga 20\% pada kasus seminoma dan 42\% pada kasus MGCT. ${ }^{1,9}$ Untuk membedakan dengan fokus koriokarsinoma, pada seminoma harus ditemukan dua jenis sel trofoblas yaitu sinsitiotrofoblas dan sitotrofoblas. ${ }^{1,2}$ Kadar HCG yang meningkat lebih berkorelasi dengan status metastastik dari pada dengan prognostik. ${ }^{1}$ Pada kasus ini ditemukan sedikit sel-sel sinsitiotrofoblas yang tersebar dan peningkatan ringan kadar $\beta$ HCG.

AFP merupakan salah satu tanda yang sensitif untuk NSGCT. ${ }^{16}$ Sel-sel seminoma tidak menyekresi AFP sehingga kadar AFP tidak meningkat. ${ }^{14,15}$ Bila serum AFP meningkat pada seminoma, harus dicari komponen YST atau dibuat pewarnaan imunoperoksidase untuk menemukan YST yang secara morfologik mirip seminoma. ${ }^{2}$ Berhubung kadar AFP serum pada kasus ini tinggi (>1.000 ng/ml) maka pemeriksaan mikroskopik dilanjutkan pada bagian lain dari massa tumor dan ternyata ditemukan komponen YST. Berdasarkan hal ini, pada setiap tumor testis perlu pemeriksaan serum penanda tumor AFP dan $\beta$ HCG untuk membantu menegakkan diagnosis yang tepat. Beberapa peneliti berpendapat bahwa kadar AFP dapat diobservasi pada seminoma murni. Terdapat dua studi yang menemukan kasus jarang dari seminoma klasik dengan peningkatan AFP serum, tetapi secara histologik tidak ditemukan komponen YST. Yuasa melaporkan terdapatnya mRNA AFP pada kasus seminoma. ${ }^{10}$

LDH dapat diekspresi pada banyak jaringan. Peningkatan kadar enzim ini dapat disebabkan oleh berbagai penyakit yang bervariasi luas. Walaupun spesifisitas rendah, LDH merupakan penanda yang bermanfaat khususnya untuk penentuan stadium seminoma dan NSGCT. ${ }^{2,8,10}$ Pada kasus ini kadar enzim LDH tidak diperiksa.

Beberapa penanda jaringan telah ditentukan antara lain placental alkaline phosphatase (PLAP), c-kit, CD 30, AFP, HCG, dan OCT $3 / 4{ }^{8}$ Umumnya YST diwarnai oleh AFP tetapi dalam bentuk fokal dan hanya sedikit, ditemukan pada sekitar 50-100\% kasus. ${ }^{1,14}$ Hasil AFP negatif pada sel-sel tumor yang tidak mengeksklusi YST.

Beberapa laporan mengemukakan bahwa seminoma anaplastik lebih agresif daripada seminoma klasik tanpa memandang stadiumnya. Penelitian lain mendapatkan bahwa seminoma anaplastik lebih sering pada lesi dengan stadium yang lebih tinggi, tetapi tidak lebih agresif daripada seminoma klasik. ${ }^{3}$ Terdapat beberapa studi yang mengemukakan prognosis seminoma anaplastik lebih buruk, ${ }^{1}$ tetapi penelitian lainnya tidak menemukan perbedaan prognosisnya dengan seminoma klasik. $^{3}$ Terdapatnya sel-sel sinsiotrofoblas tidak memengaruhi prognosis seminoma tetapi lebih berhubungan dengan metastasis. ${ }^{10}$ Tidak terdapatnya limfosit pada stroma disertai corak pertumbuhan intertubuler yang pre-dominan menunjukkan prognosis buruk. $^{3}$ Dibandingkan dengan seminoma, NSGCT secara biologik lebih agresif dan umumnya mempunyai prognosis lebih buruk. ${ }^{10}$

Adanya komponen YST berhubungan erat dengan metastasis. ${ }^{13}$ Avasthi et al $^{11}$ melaporkan kasus seorang laki-laki berusia 21 tahun dengan MGCT testis yang telah dioperasi dua tahun lalu, kemudian ditemukan bermetastasis ke jantung. Banyaknya komponen seminoma, teratoma, atau YST berkorelasi positif dengan prognosis, tetapi banyaknya karsinoma embrional dan koriokarsinoma merupakan prediksi dari progresivitas tumor. $^{10}$

Penurunan AFP atau HCG serum menunjukkan adanya respon terhadap terapi. 
Peningkatan penanda yang persisten setelah kemoterapi mengindikasikan terdapatnya penyakit residual atau metastasis, dan perlu diterapi lebih lanjut. ${ }^{8}$ Penurunan penanda yang lambat menunjukkan risiko buruk untuk pasien dan perlu diberikan terapi yang lebih agresif. Setelah terapi berhasil, semua pasien perlu dimonitor secara kontinyu. Faktor penting dalam menentukan kesembuhan ialah pemberian terapi yang lengkap dan follow up pasien secara teratur.

Prognosis tumor testis sebagian besar tergantung pada stadium klinis, jenis histologik, dan terapi yang diberikan. ${ }^{13}$

\section{SIMPULAN}

Telah dilaporkan kasus seorang lakilaki berusia 38 tahun dengan diagnosis histopatologik awal seminoma anaplastik. Hasil pemeriksaan AFP serum 1.069 ng/ml dan $\beta$ HCG serum $1.026 \mathrm{mIU} / \mathrm{ml}$. Oleh karena terdapatnya peningkatan serum AFP maka dilakukan pemeriksaan jaringan lanjut dan ternyata ditemukan komponen YST sehingga diagnosis akhir ialah mixed germ cell tumor testis. Pada kasus tumor testis sangat dibutuhkan pemeriksaan AFP dan $\beta$ HCG serum untuk membantu menegak̄kan diagnosis.

\section{DAFTAR PUSTAKA}

1. Tickoo SK, Amin MB, Cramer HM, Harik LR, Ulbright TM. Tumor of the testis. In: Silverberg SG, Dehellis RA, Frable WJ, Livolsi VA, Mark R, editors. Silverberg's Principles \& Practice of Surgical Pathology \& Cytopathology Vol 2 (Fourth Edition). Philadelphia: Elsevier, 2006; p.174160.

2. Kirk JW, Louis RB. Testicular tumor pathology. In: Foulkes WD, Cooney KA, editors. Reproductive Cancer. New York: Springer, 2009; p.121-35.

3. Rosai J. Testis. In: Rosai J, editor. Rosai \& Ackerman's Surgical Pathology Vol 1 (Tenth Edition). Philadelphia: Elsevier, 2011; p.1338-51.

4. Avi SR, Barnett SK. Testicular carcinoma. In: Abraham J, Gulley JL, Allegra CJ, editors. Bethesda Handbook of Clinical Oncology (Second Edition). Philadelphia, PA: Lippincott Williams \& Wilkins, 2005; p.211-20.

5. Satish KT, Pheroze T, Mahul BA. Testis \& paratestis. In: Weidner $\mathrm{N}$, Cote RJ, Suster S, Weiss L, editors. Modern Surgical Pathology Vol 2 (Second Edition). Philadelphia: Saunder Elsevier, 2009; p.1197-1220.

6. Epstein J. Testicular tumor. In: Kumar V, Abbas AK, Fausto N, Aster J C, editors. Robbins and Cotran Pathologic Basis of Diseases (Eight Edition). Philadelphia: Saunders Elsevier, 2010; p.2146-59.

7. Mostofi FK, Sesterlernn IA. Tumours of the testis \& paratestis tissue. In: Eble JN, Sauter G, Epstein J, Sesterhernn IA, editors. WHO Classification of Tumours Pathology \& Genetic of Tumour of the Urinary System \& Male Genital Organ. Lyon: IARC Press, 2004; p.217-232.

8. Stenman UH, Lamerz R, Looijenga LH, Bost GJ. Tumor markers in testicular cancers. In: The National Academy of Clinical Biochemistry. Laboratory medicine practice guidelines: use of tumor markers in testicular, prostate, colorectal, breast and ovarian cancers [homepage on the Internet]. 2009 [updated 2012 Jul 25; cited 2013 Jun 11]. Available from: http://www.aacc. org/members/nacb/LMPG/OnlineGuide /PublishedGuidelines/major/Documents /Chapter2.pdf

9. Sesterhernn IA, Davis CJ. Pathology of germ cell tumors of the testis. Cancer Control. 2004;11(6):374-85.

10. Petersen RO, Sesterhenn IA, Davis CJ. Testis. In: Petersen RO, editor. Urology Pathology (Third Edition). Philadelphia: Lippincott Williams \& Wilkins, 2009; p.1028-73.

11. Avasthi R, Chaudhary SC, Mohanty D, Kiran M. Testicular mixed germ cell tumor metastasizing to heart. JAPI. 2008;56:812-5.

12. Molavi DW. Testis. In: Molawi DW, editor. The Practice of Surgical Pathology: A Beginner's Guide to the Diagnostic Process. New York: Springer, 2008; p.128-36.

13. Stamatiou K, Papadopoulos $P$, Perlepes G. Mixed germ cell tumor of the 
testicle with rhabomyosarcomatous component. Case Journal. 2009;2:9299.

14. Pins MR. Male Genitourinary System. In: Gattuso P, Reddy VB, David O, Spitz DJ, Haber MH, editors. Differential Diagnosis in Surgical Pathology (Second Edition). Philadelphia:
Saunders Elsevier, 2010; p.539-96.

15. Mikuz G, Colecchia M. Tumor of the testis \& paratesticular structures. In: Mikuz G, editor. Clinical pathology of urological tumors. London: Informa Healthcare, 2007; p.161-75. 